\title{
Characteristics of Bacteriostasis in Natural Soils
}

\author{
By W. H. KO AND FRANCES K. CHOW \\ Department of Plant Pathology, University of Hawaii, Beaumont Agricultural \\ Research Center, Hilo, Hawaii 96720, U.S.A.
}

(Received 24 November; revised 14 February 1977)

\begin{abstract}
Streptomycin-resistant bacteria were added to natural soil and their numbers were determined at 0 and $24 \mathrm{~h}$ using soil extract agar supplemented with streptomycin. None of 10 rhizosphere and Io non-rhizosphere bacteria tested increased in number in soil. Moreover, no increase was detected when six identified bacteria were added to soil. Agrobacterium radiobacter did not increase in any of seven soils tested. However, its population increased greatly in autoclaved soil as well as in nutrient-amended soil. The bacterium did not grow in distilled water, but grew abundantly in a nutrient solution. The characteristics of soil bacteriostasis appear to be similar to those of soil fungistasis.
\end{abstract}

\section{INTRODUCTION}

Soil bacteriostasis has been detected by measuring the diameter of bacterial colonies on agar discs after 2 or 7 days incubation on filter paper placed on soil (Brown, 1973; Davis, 1975). We found that after 2 days incubation on filter paper placed on soil, agar discs were contaminated with fungi, other bacteria and even nematodes. It was very difficult to differentiate the test bacteria from contaminants. Moreover, interpretation of the observed results was complicated by the stimulatory effect of nutrients present in agar discs and filter paper (Ko \& Lockwood, 1967). Since streptomycin-resistant strains of bacteria in soil can be quantitatively assayed by the soil-dilution-plate method on media supplemented with streptomycin, they were used to re-evaluate soil bacteriostasis and to determine the characteristics of this natural microbial antagonism of soil.

\section{METHODS}

Soils. Soils were sieved and kept in moist conditions in plastic containers. Soil A (pH 5.3) was fine sandy loam; soil B (pH 5.1) and C (pH 5.2), silty clay loam; soil D (pH 5.9) and F (pH 6.7), loam; soil E (pH 5.2), light clay loam; and soil G (pH 8.3), clay loam. Soil A, B, C, D and E were collected from Hawaii; soil F, Michigan; soil G, Colorado. Sandy loam soil ( $\left.\mathrm{pH}_{5} \cdot 9\right)$ was used in all experiments except when different soils were needed for comparison.

Isolation of bacteria. To isolate rhizosphere bacteria, $3 \mathrm{~g}$ of roots from 7-day-old mung bean seedlings grown in sandy loam soil were gently washed free of soil particles in sterile distilled water and ground with $100 \mathrm{ml}$ sterile distilled water in an Omni-Mixer (Du Pont Co., U.S.A.) at $2500 \mathrm{rev}$. $\mathrm{min}^{-1}$ for $30 \mathrm{~s}$. The diluted suspension was plated on PCNB/soil extract agar developed by Farley \& Lockwood (I968). Individual colonies were transferred to nutrient agar $\left(\mathrm{g} \mathrm{l}^{-1}\right.$ : maltose, 10; yeast extract, 4; glucose, 4; and agar, 20) slants after 5 days incubation at $24^{\circ} \mathrm{C}$. Non-rhizosphere bacteria, obtained from soil away from roots were isolated by plating diluted soil suspension on PCNB/soil extract agar as described above.

Assay of soil bacteriostasis. Streptomycin resistance was induced by growing sequentially in nutrient agar containing $0.05,0 . \mathrm{I}, 0.5, \mathrm{I} \cdot 0$, and $2.0 \mathrm{mg}$ streptomycin sulphate $\mathrm{ml}^{-1}$. Streptomycin-resistant bacteria were maintained on nutrient agar supplemented with $2 \mathrm{mg}$ streptomycin sulphate $\mathrm{ml}^{-1}$.

About $0.05 \mathrm{~g}$ of bacteria from a 2-day-old culture on nutrient agar was suspended in $10 \mathrm{ml}$ sterile distilled water. The bacterial suspension was diluted to $\mathrm{I} / \mathrm{IO}$, and $\mathrm{I} \mathrm{ml}$ of the diluted suspension was mixed with $10 \mathrm{~g}$ 
of soil in a Petri dish.The inoculated soil had a moisture content of about $90 \%$ water-holding capacity; it was incubated at $24^{\circ} \mathrm{C}$. At $\mathrm{o}$ and $24 \mathrm{~h}$, a $1 \cdot 3 \mathrm{~g}$ sample was diluted with sterile distilled water to $10^{-5}, \mathrm{10}^{-6}$ and $\mathrm{IO}^{-7}$. The diluted soil suspensions were plated on soil extract agar supplemented with $\mathrm{I} \cdot 0 \mathrm{mg}$ streptomycin sulphate $\mathrm{ml}^{-1}$. Five plates were used for each dilution and the experiments were repeated at least once. Student's $t$ test was used to compare the population means at 0 and $24 \mathrm{~h}$.

\section{RESULTS}

None of 10 rhizosphere or 10 non-rhizosphere bacteria tested increased in number in natural soil (Table I). The populations of 10 rhizosphere and 6 non-rhizosphere bacteria remained more or less constant in soil for $24 \mathrm{~h}$, but those of 4 non-rhizosphere bacteria decreased. Also, no increase in population was detected when the following bacteria were added to soil: Agrobacterium radiobacter, Agrobacterium tumefaciens, Bacillus megaterium, Bacillus subtilis, Pseudomonas solanacearum and Serratia marcescens (Table 2). Four of these did not change significantly in number in soil, but the populations of $B$. megaterium and $P$. solanacearum decreased.

Different types of soils were also tested using $A$. radiobacter as the test organism. The population of $A$. radiobacter either remained constant or decreased in each of the seven soils tested (Table 3).

In natural soil the population of $A$. radiobacter remained more or less constant for 4 days, but in autoclaved soil the number increased continuously from $5 \times 10^{6}$ to $3 \times 10^{16}(\mathrm{~g}$ dry soil $)^{-1}$ during the same period. In natural soil supplemented with $\mathrm{I} \%(\mathrm{w} / \mathrm{w})$ glucose and $1 \%(w / w)$ peptone, the population of $A$. radiobacter increased 50 to 100 times in $24 \mathrm{~h}$. In sterile distilled water $A$. radiobacter decreased to one-eighth of the original population in $24 \mathrm{~h}$, but its numbers increased 20000 -fold in a solution containing $1 \%$ glucose and $\mathrm{I} \%$ peptone. In each case suspensions were incubated at $24^{\circ} \mathrm{C}$.

\section{DISCUSSION}

The method we used was apparently more sensitive for assaying soil bacteriostasis than the agar disc method. Using this method, Brown (1973) found that most rhizosphere bacteria were sensitive, but non-rhizosphere bacteria were not sensitive to soil bacteriostasis. However, when bacteria were added directly to soil, we found that both rhizosphere and non-rhizosphere bacteria were sensitive to soil bacteriostasis. The behaviour of streptomycinresistant bacteria in soil was presumed to be the same as that of their parent isolates. Hsieh, Buddenhagen \& Kauffman (1974) showed that streptomycin-resistant Xanthomonas oryzae was identical with its parent isolate in virulence and in 30 physiological characters.

Our results showed that soil bacteriostasis was widespread in natural soils and was effective against all bacteria tested. The bacteriostatic property of soil disappeared when soil was sterilized or supplemented with nutrients. Therefore, the characteristics of soil bacteriostasis were similar to those of soil fungistasis. Similar results were reported by Davis (1976) using the agar disc method.

Based on the information currently available in the literature, microbiostasis of natural soil includes: (i) inhibition of fungal spore germination and growth, commonly called fungistasis (Dobbs \& Hinson, 1953); (ii) inhibition of actinomycete spore germination and growth (actinostasis) (Lloyd, 1969); and (iii) inhibition of bacterial spore germination (Jackson \& Brown, 1966; Siala \& Gray, 1974), and of bacterial cell growth (Brown, 1973), commonly called bacteriostasis. One of the hypotheses for soil fungistasis is the presence of fungistatic substances of microbial origin in soil. However, it is very unlikely that inhibitory substances are produced by micro-organisms in natural soils away from plant roots and undecomposed organic materials, since all the three major groups of micro-organisms 
Table I. Susceptibility of rhizosphere and non-rhizosphere bacteria to soil bacteriostasis

Rhizosphere bacteria *

\begin{tabular}{|c|c|c|}
\hline \multirow[b]{2}{*}{ Isolate } & \multirow[b]{2}{*}{ Incubation time (h) } & $\begin{array}{c}10^{-5} \times \\
\text { no. (g dry soil })^{-1}\end{array}$ \\
\hline & & 24 \\
\hline I & 290 & 260 \\
\hline 2 & I 54 & 167 \\
\hline 3 & 30 & 10 \\
\hline 4 & 6 & 8 \\
\hline 5 & 15 & 15 \\
\hline 6 & 300 & 400 \\
\hline 7 & 400 & 312 \\
\hline 8 & 130 & 130 \\
\hline 9 & 200 & 400 \\
\hline 10 & 150 & 200 \\
\hline
\end{tabular}

Non-rhizosphere bacteria

$\begin{array}{crr}\text { Isolate Incubation time (h) } \ldots & 0 & 24 \\ 1 & 40 & 40 \\ 2 & 8 & 9 \\ 3 & 174 & 234 \\ 4 & 51 & 46 \\ 5 & 24 & 19 \\ 6 & 50 & 46 \\ 7 \dagger & 100 & 17 \\ 8 \dagger & 54 & 17 \\ 9 \dagger & 31 & 5 \\ 10 \dagger & 67 & 10\end{array}$

* Bacteria were isolated from the rhizosphere of mung bean seedlings.

$\dagger$ The values at $\mathrm{oh}$ and $24 \mathrm{~h}$ for these isolates were significantly different at $P=0.5$.

Table 2. Susceptibility of six identified bacteria to soil bacteriostasis

\section{Bacterium}

Agrobacterium radiobacter

A. tumefaciens

Bacillus megaterium*

B. subtilis

Pseudomonas solanacearum*

Serratia marcescens
$10^{-5} \times$ no. of bacteria (g dry soil) $)^{-1}$

\begin{tabular}{|c|c|c|}
\hline Incubation time (h) ... & 0 & 24 \\
\hline & 94 & 9 I \\
\hline & 13 & 15 \\
\hline & $\infty$ & \\
\hline & 4 & \\
\hline & 59 & \\
\hline & 44 & 216 \\
\hline
\end{tabular}

* The values at $\mathrm{oh}$ and $24 \mathrm{~h}$ for these bacteria were significantly different at $P=0.5$.

Table 3. Growth of Agrobacterium radiohacter in seven different soils

\begin{tabular}{|c|c|c|}
\hline \multirow[b]{2}{*}{ Soil* } & \multirow[b]{2}{*}{ Incubation time $(h) \ldots$} & $\begin{array}{c}10^{-5} \times \text { no. of bacteria } \\
(\mathrm{g} \text { dry soil })^{-1}\end{array}$ \\
\hline & & 24 \\
\hline A & 88 & 42 \\
\hline B & 19 & I3 \\
\hline C & 340 & 160 \\
\hline D十 & 64 & 9 \\
\hline $\mathrm{E} \dagger$ & 75 & $\mathbf{I}$ \\
\hline$F$ & 14 & 14 \\
\hline G & 50 & 42 \\
\hline
\end{tabular}

- A was a fine sandy loam; B and C, silty clay loam; D and F, loam; E, light clay loam; G, clay loam.

$\dagger$ The values at $\mathrm{h}$ and $24 \mathrm{~h}$ for these soils were significantly different at $P=0.5$.

(bacteria, actinomycetes and fungi) are sensitive to microbiostasis of soil. Instead it seems more likely that soil microbiostasis is due to nutrient deprivation, as shown previously for fungi (Ko \& Lockwood, 1967). Davis (1976) failed to demonstrate bacteriostatic substances in soil extracts or in agar discs previously incubated on soil, and was unable to detect volatile inhibitors emanating from soil. Based on the study of the relation between soil bacteriostasis and bacterial nutrition, he suggested that, like soil fungistasis, the bacteriostatic effect of soil could be satisfactorily explained by nutrient competition. 
Journal Series Paper No. 2069 of the Hawaii Agricultural Experiment Station. Supported in part by a grant from the McIntire-Stennis Cooperative Forestry Research Program. We thank R. Baker and J. L. Lockwood for the gift of Colorado and Michigan soil, respectively.

\section{REFERENCES}

Brown, M. E. (1973). Soil bacteriostasis limitation in growth of soil and rhizosphere bacteria. Canadian Journal of Microbiology 19, 195-199.

DAvis, R. D. (1975). Bacteriostasis in soils sterilized by gamma irradiation and in reinoculated sterilized soils. Canadian Journal of Microbiology 21, 481-484.

DAVIS, R. D. (1976). Soil bacteriostasis: relation to bacterial nutrition and active soil inhibition. Soil Biology and Biochemistry 8, 429-433.

Dobrs, C. G. \& Hinson, W. H. (I953). A widespread fungistasis in soils. Nature, London 172, 197-199.

FARLEY, J. D. \& LOCKWOOD, J. L. (1968). The suppression of actinomycetes by PCNB in culture media used for enumerating soil bacteria. Phytopathology 58, 714-7I5.

Hsieh, S. P. Y., Buddenhagen, I. W. \& Kauffman,
H. E. (1974). An improved method for detecting the presence of Xanthomonas oryzae in rice seed. Phytopathology 64, 273-274.

JACKSON, R. M. \& BRown, M. E. (1966). Behaviour of Azotobacter chroococcum introduced into the plant rhizosphere. Annales de l'Institut Pasteur I1 103-II 2.

Ko, W. H. \& Lockwood, J. L. (1967). Soil fungistasis: relation to fungal spore nutrition. Phytopathology 57, 894-901.

LLOYD, A. B. (1969). Behaviour of streptomycetes in soil. Journal of General Microbiology 56, 165-1 70.

Siala, A. \& Gray, T. R. G. (1974). Growth of Bacillus subtilis and spore germination in soil observed by a fluorescent-antibody technique. Journal of General Microbiology 81, 19 I-198. 